\title{
NEW ASIAN LOCALITIES OF HYMENOSTYLIUM XEROPHILUM AND H. GRACILLIMUM
} О НОВЫХ НАХОДКАХ НYMENOSTYLIUM XEROPHILUM И H. GRACILLIMUM В АЗИИ

\author{
Elena A. IGNATOVA ${ }^{1}$, Michael S. IGNATOV ${ }^{1,2}$, Alina V. FedOROVA ${ }^{2} \&$ JAN KUČERA $^{3}$ \\ ЕЛЕНА А. ИГНАТОВА ${ }^{1}$, МИХАИЛ С. ИГНАТОВ ${ }^{1,2}$, АЛИНА В. ФЕДОРОВА $^{2}$, ЯН КУЧЕРА ${ }^{3}$
}

Abstract

\begin{abstract}
We report here the new, highly disjunct Asian occurrences for two Hymenostylium species, which have so far only been known from Europe. Hymenostylium xerophilum is newly reported from Oman and eastern Yakutia, while the other species, H. gracillimum was found among herbarium material collected at the shore of Lake Baikal in southern Siberia. While the new H. xerophilum records matched both the earlier described morphology of the plants and ecological preferences, the plants of $H$. gracillimum were morphologically and probably also ecologically rather distinct from the known European material. Molecular phylogenetic analysis of Pottiaceae trib. Pleuroweisieae based on nuclear ITS region and two chloroplast loci was performed to assess newly the phylogenetic affinities of the two species and to confirm the identity with the European plants. The lineage formed by accessions of these two species was confirmed as rather distinct from the rest of analyzed Hymenostylium taxa and pointed to the necessity of a large-scaled study of Hymenostylium and related genera. We discuss the ecological and phytogeographic characteristics of the new Asian occurrences.
\end{abstract}

резюме

Приводятся новые находки в Азии широко дизъюнктивных видов из рода Hymenostylium, которые до настоящего времени были известны только из Европы. Hymenostylium xerophilum впервые найден в Омане и в восточной Якутии, а H. gracillimum выявлен в гербарных коллекциях с побережья озера Байкал на юге Сибири. В то время как новый образец H. xerophilum полностью соответствует опубликованному описанию этого вида и его экологическим предпочтениям, то растения H. gracillimum из местонахождения на Байкале оказались существенно отличающимися по морфологии и, возможно, экологическим характеристикам от известных европейских популяций. Молекулярно-филогенетический анализ Pottiaceae trib. Pleuroweisieae, основанный на ядерном участке ITS и двух хлоропластных маркерах, $r p s 4$ и $\operatorname{trn} M-\operatorname{trn} V$, был выполнен с целью подтверждения филогенетического родства этих двух видов и соответствия их новых находок европейскому материалу. Анализ последовательностей ДНК изученных маркеров H. xerophylum и H. gracillimum подтвердил их отграниченность от остальных видов рода Hymenostylium и указал на необходимость широкомасштабного изучения комплекса близких к нему родов. В статье также обсуждаются экологические и фитогеографические характеристики азиатских популяций.

KEYWORDS: Hymenostylium, Pleuroweisieae, Asia, Siberia, disjunct distribution, metalliferous rocks, molecular phylogeny, ITS, rps4, trnM-trnV

\section{INTRODUCTION}

Hymenostylium xerophilum Köckinger \& J.Kučera and $H$. gracillimum (Nees \& Hornsch.) Köckinger \& J.Kučera are two closely related species, which were recently described, respectively re-established as species from European material in the treatment by Köckinger \& Kučera (2011). Both species escaped nearly completely the attention of European bryologists despite the fact that at least $H$. xerophilum cannot be regarded a rare species. Indeed, it was discovered at about 35 localities in the Austrian Alps in course of a focused search conducted by H. Köckinger between 1994 and 2009. The second species, $H$. gracillimum, was described three times from Europe even though it is a smaller, less apparent species, which seems to be significantly rarer than $H$. xerophilum. On the other hand, the two historical descriptions of $H$. gracillimum fell in oblivion soon after their publication, and the modern re-description of the

\footnotetext{
1 - Lomonosov Moscow State University, Faculty of Biology, Plant Ecology and Geography Dept., Leninskie Gory Str. 1-12, Moscow 119234 Russia - Россия, 119234, Москва, Ленинские Горы, д. 1 стр. 12, Московский государственный университет, биологический факультет, кафедра экологии и географии растений; e-mails: arctoa@list.ru, misha ignatov@list.ru

2 - Tsitsin Main Botanical Garden, Russian Academy of Sciences, Botanicheskaya Str., 4, Moscow $12 \overline{7} 276$ Russia - Россия 127276 Москва, Ботаническая 4, ГБС РАН; e-mail: alina 77777@mail.ru

3 - University of South Bohemia, Faculty of Science, Department of Botany, Branišovská 1760, CZ-370 05 České Budějovice, Czech Republic, e-mail: kucera@prf.jcu.cz
} 
Fig. 1. Boostrap consensus tree showing branch lengths from the Maximum Likelihood analysis of the nuclear ITS sequence data. Bootstrap values (912 replicates) appear above the lines and posterior probabilities from the Bayesian inference are shown below the lines.
76

- Hymenostylium recurvirostrum Tajikistan Hymenostylium recurvirostrum Austria Buers

- Hymenostylium recurvirostrum Austria Seidlwinkltal

51 1 80 Hymenostylium recurvirostrum agg. Russia Irkutskaya 1. Hymenostylium recurvirostrum agg. Japan

0.98 Hymenostylium recurvirostrum agg. Russia Zabaykalsky

56 Hymenostylium recurvirostrum var. insigne Scotland

9 Hymenostylium recurvirostrum var. insigne Austria

1 Hymenostylium recurvirostrum agg. Greece

- Hymenostylium recurvirostrum agg. India

99. Hymenostylium aurantiacum India Lueth 6596

91 Hymenostylium aurantiacum India Lueth 6628

1100 Hymenostylium xanthocarpum India Lueth 6624

1 Hymenostylium xanthocarpum India Lueth 6596

- Hymenostylium hildebrandtii Morocco

- Hymenostylium xerophilum Russia

71 Hymenostylium xerophilum Austria Krastal

Hymenostylium xerophilum Oman

63. Hymenostylium xerophilum Austria Mt Reiting

- Hymenostylium gracillimum Karelia

$67 \quad 93$ Hymenostylium gracillimum Austria Tiboldgraben

Hymenostylium gracillimum Austria Weissensee

$\frac{78}{0.99}$ Hymenostylium gracillimum Austria Virgental

Hymenostylium gracillimum Russia

Molendoa hornschuchiana Austria Heiligenblut

64 Molendoa tenuinervis Austria

Molendoa hornschuchiana Austria Seidlwinkltal

Molendoa sendtneriana Russia

Molendoa sendtneriana Austria

- Molendoa tenuinervis Mongolia - Tuerckheimia valeriana Costa Rica

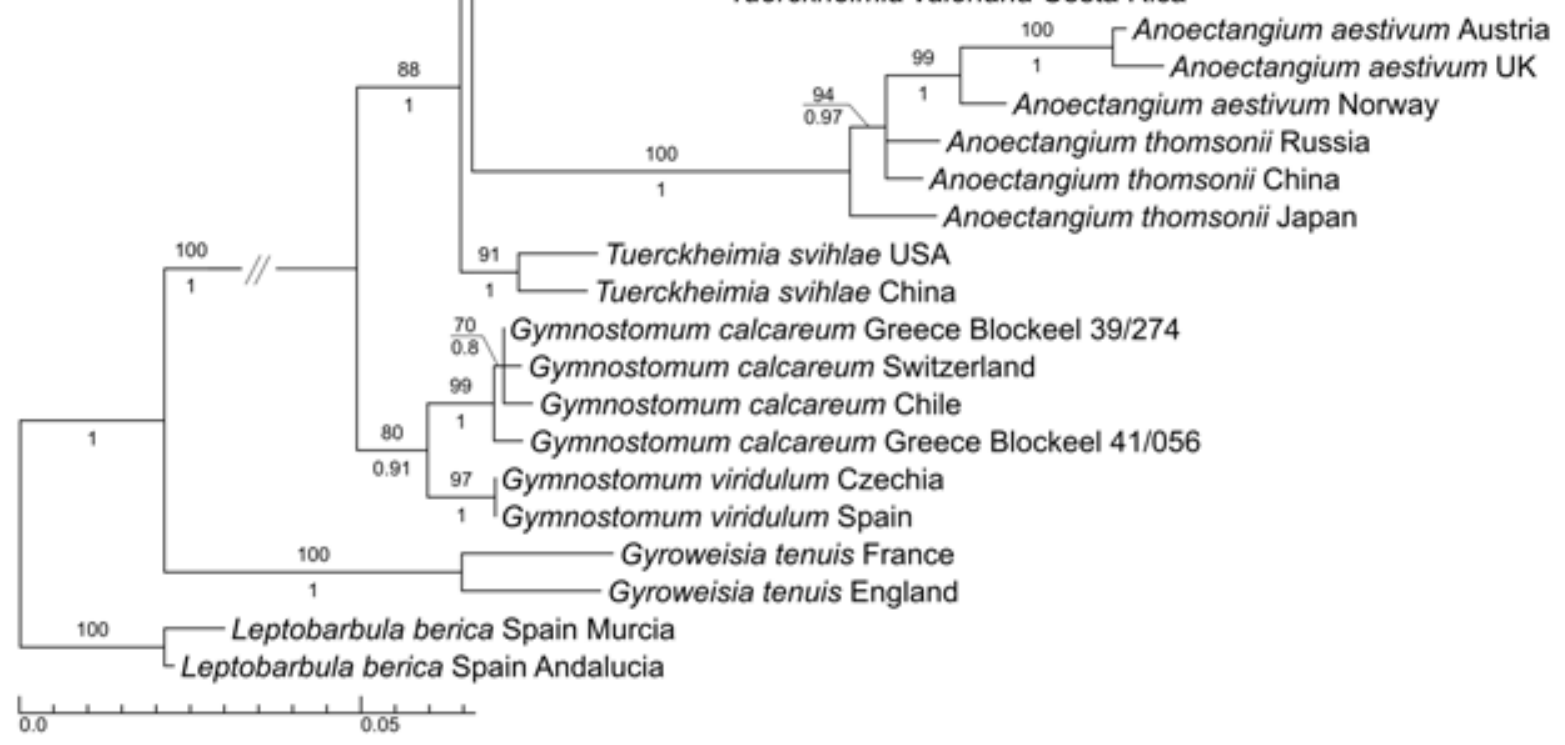

species (as Gymnostomum boreale Nyholm \& Hedenäs) has not been understood correctly by most authors, which resulted in the common confusion of that species with Gymnostomum aeruginosum $\mathrm{Sm}$.

Both species have so far only been known from Europe (Austrian and Bavarian Alps plus one Fennoscandian outpost of $H$. gracillimum in Karelia; the earlier reports of $H$. gracillimum (as Gymnostomum boreale) from Norway, Slovakia, North America (Québec, Canada) and northern Siberia (Taimyr) were proven wrong by
Köckinger \& Kučera (2011), although the authors speculated that the real distribution of both species is likely much wider, despite their search in herbaria was not successful.

The first records of $H$. xerophilum outside the distribution area presented by Köckinger \& Kučera (2011) succeeded independently in course of the revision of selected genera of Pottiaceae during a SYNTHESYS-funded stay of J. Kučera in the herbarium of Royal Botanic Garden Edinburgh, and during the treatment of material col- 
Fig. 2. Boostrap consensus tree showing branch lengths from the Maximum Likelihood analysis of the concatenated chloroplast rps4-trnS and trnM-trnV sequence data, supplemented by the partition of indels scored using the simple coding method of Simmons \& Ochoterena (2000). Bootstrap values (560 replicates) appear above the lines and posterior probabilities from the Bayesian inference are shown below the lines.

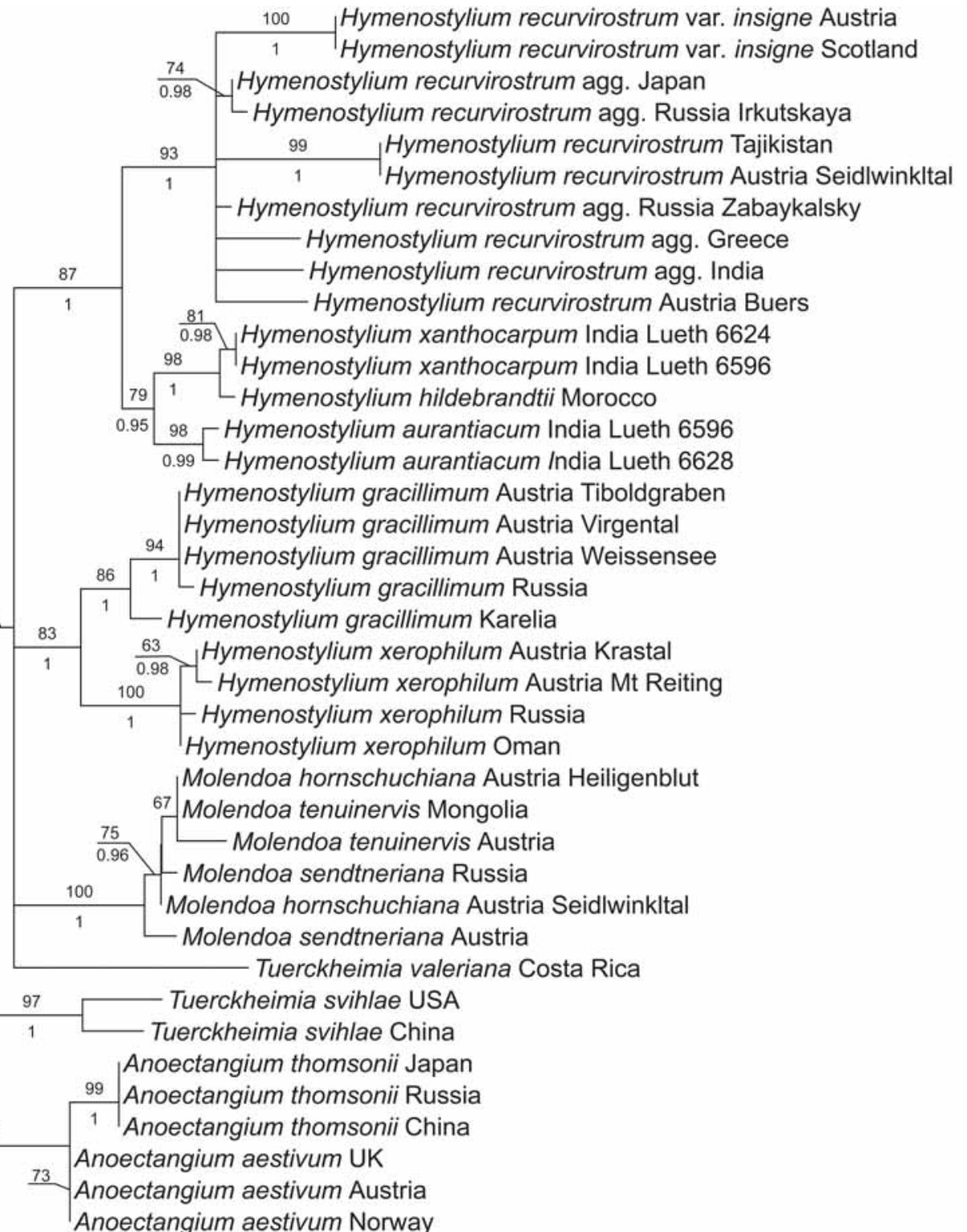

100 Hymenostylium recurvirostrum var. insigne Austria Hymenostylium recurvirostrum agg. Japan Hymenostylium recurvirostrum agg. Russia Irkutskaya $1 \quad$ Hymenostylium recurvirostrum Austria Seidlwinkltal Hymenostylium recurvirostrum agg. Russia Zabaykalsky

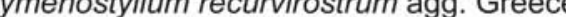
Hymenostylium recurvirostrum agg. India 0.98 Hymenostylium xanthocarpum India Lueth 6624 98 Hymenostylium xanthocarpum India Lueth 6596 0.99 L Hymenostylium aurantiacum India Lueth 6628 Hymenostylium gracillimum Austria Tiboldgraben Hymenostylium gracillimum Austria Virgental Hymenostylium gracillimum Austria Weissensee

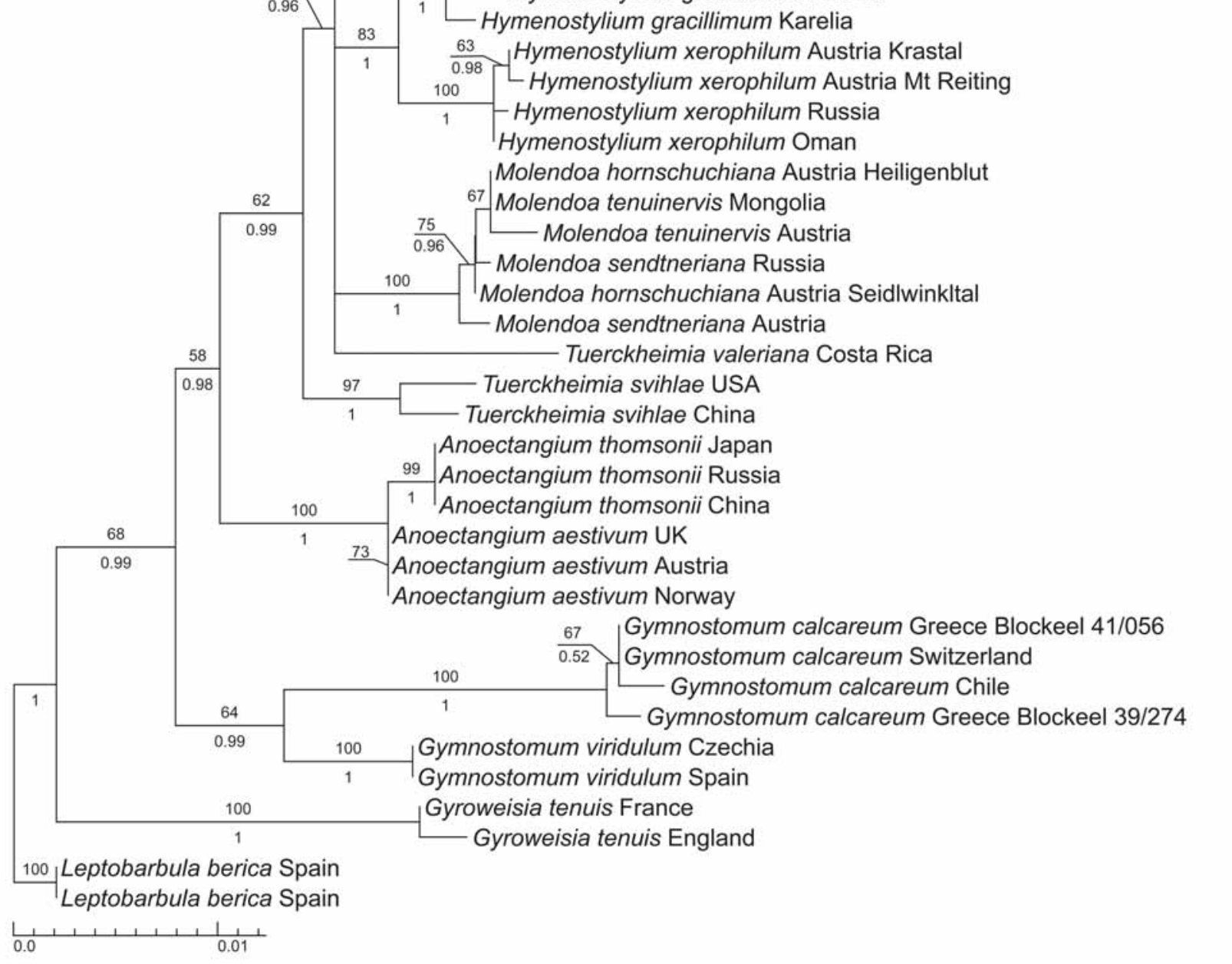

lected in course of the expedition to the Sette-Daban mountain range in the Russian Yakutia (Ignatova \& al., 2018). In the former case, one specimen collected by W. Frey \& H. Kürschner in Oman and labelled Gymnostomum mosis (Lorentz) Jur. \& Milde, in the latter case a specimen collected in the Kuraanakh River valley drew our attention as the possible specimens of $H$. xerophilum. The third Hymenostylium specimen, which EAI and
MSI were unable to name according to morphological characters, was collected in Olkhon Island surrondings at the NW shore of Lake Baikal. In order to be assured about the identification of the two $H$. xerophilum specimens which would represent a significant range extension of the species with respect to the current knowledge, and to barcode the unnamed specimen from Olkhon Island, we decided to obtain DNA sequence data for loci 


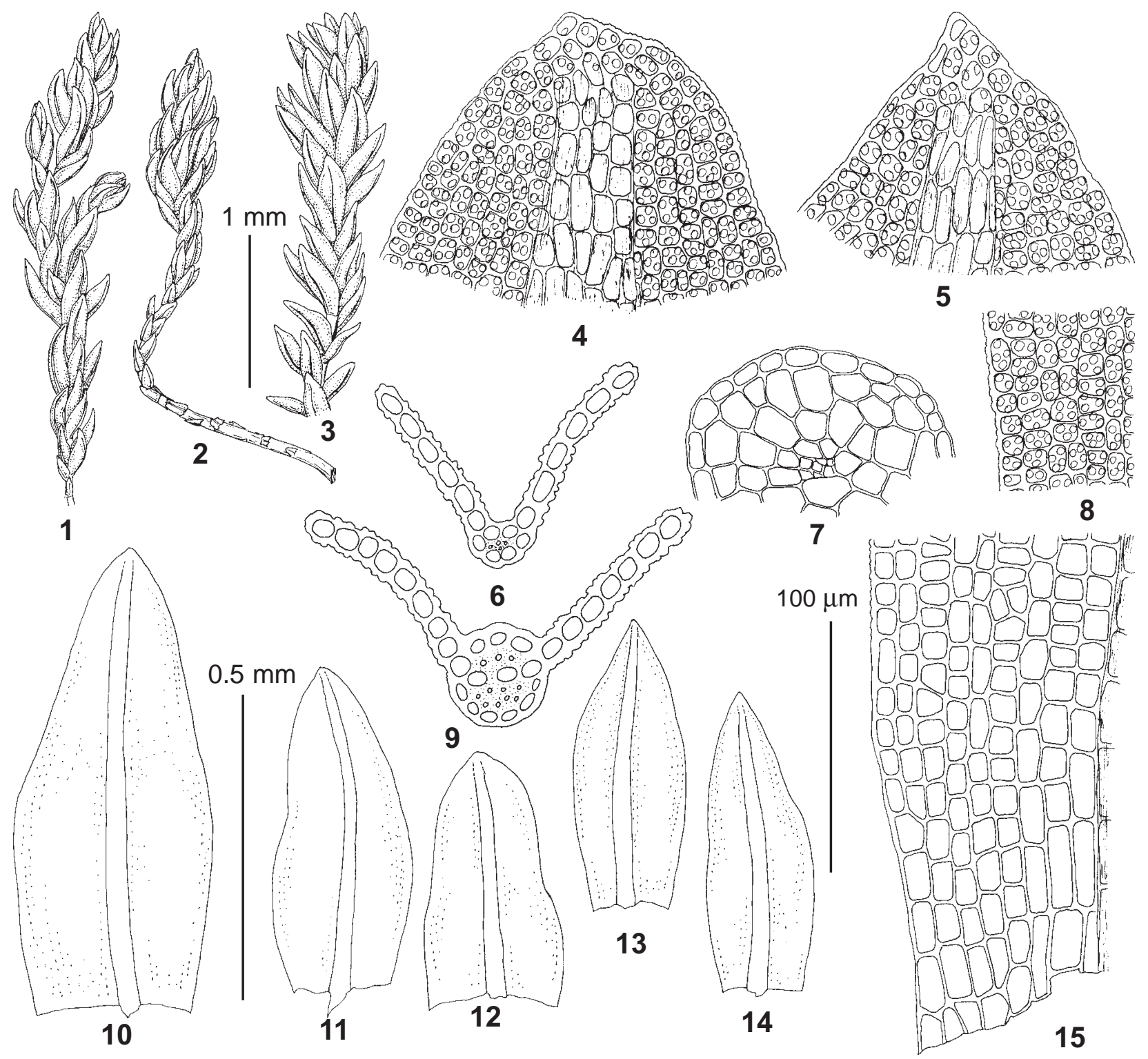

Fig. 3. Hymenostylium xerophilum (Republic of Sakha/Yakutia, Tomponsky Distr., Sette-Daban Mt. Range, 21.VII.2015, Ignatov \& Ignatova 15-851, MHA): 1-2 - habit, dry; 3-habit, wet; 4-5-upper laminal cells; 6, 9- leaf transverse sections; 7 - stem transverse section; 8 - mid-leaf cells; $10-14$ - leaves; 15 - basal laminal cells. Scale bars: $1 \mathrm{~mm}$ for $1-3 ; 0.5 \mathrm{~mm}$ for $10-14 ; 100$ $\mu \mathrm{m}$ for $4-8,15$.

well-represented in the library of Pleuroweisieae Limpr. species, i.e., nuclear ITS region, and chloroplast rps 4 and $\operatorname{trnM-trnV}$. Moreover, as the dataset of Pleuroweisieae was rather limited in the study of Köckinger \& Kučera (2011) and only one chloroplast locus was employed in that study, this was a welcome chance to explore the phylogenetic affinities of $H$. xerophilum and $H$. gracillimum within Hymenostylium Brid. and closely related taxa.

\section{MATERIAL AND METHODS}

Specimens Frey \& Kürschner 1-3949 from herbarium E (Oman, Jabal Al Akhdar bei Wakhan, Felsspalten, Kalk, 2050 m, 18.2.1983 coll. W. Frey \& H. Kürschner) and Ignatov \& Ignatova 15-851 from herbarium MHA (Russia, Yakutia, Tomponsky District, Sette-Daban Mountain Range, right slope of Kuraanakh River valley in its lower course, $63^{\circ} 02^{\prime} \mathrm{N} 138^{\circ} 23^{\prime} \mathrm{E}, 765 \mathrm{~m}$, rock outcrops in small shallow depression on rocky slope, rock fissure, 21.7.2015 coll. M.S. Ignatov \& E.A. Ignatova) morphologically matching Hymenostylium xerophilum and the specimen Bardunov s.n. from herbarium MW, duplicate from IRK (Russia, Irkutsk Province, Olkhon District, Sakhyurta [Sakhyurte in label] Settlement, $53^{\circ} 01^{\prime} \mathrm{N} 106^{\circ} 53^{\prime} \mathrm{E}$, limestone cliffs, in fissures, 31.8.1997 coll. L.V. Bardunov) morphologically only attributable to genus Hymenostylium were isolated for DNA and amplified for three loci: nuclear ribosomal ITS spanning ITS1, 5.8 rRNA and ITS2, chloroplast $r p s 4$ gene with the adjacent spacer towards trnS tRNA gene, and the trnM-trnV spacer. The specimen Frey \& Kürschner 1-3949 was extracted using the Qiagene Extractor in the facilities of Royal Botanic Gardens Edin- 

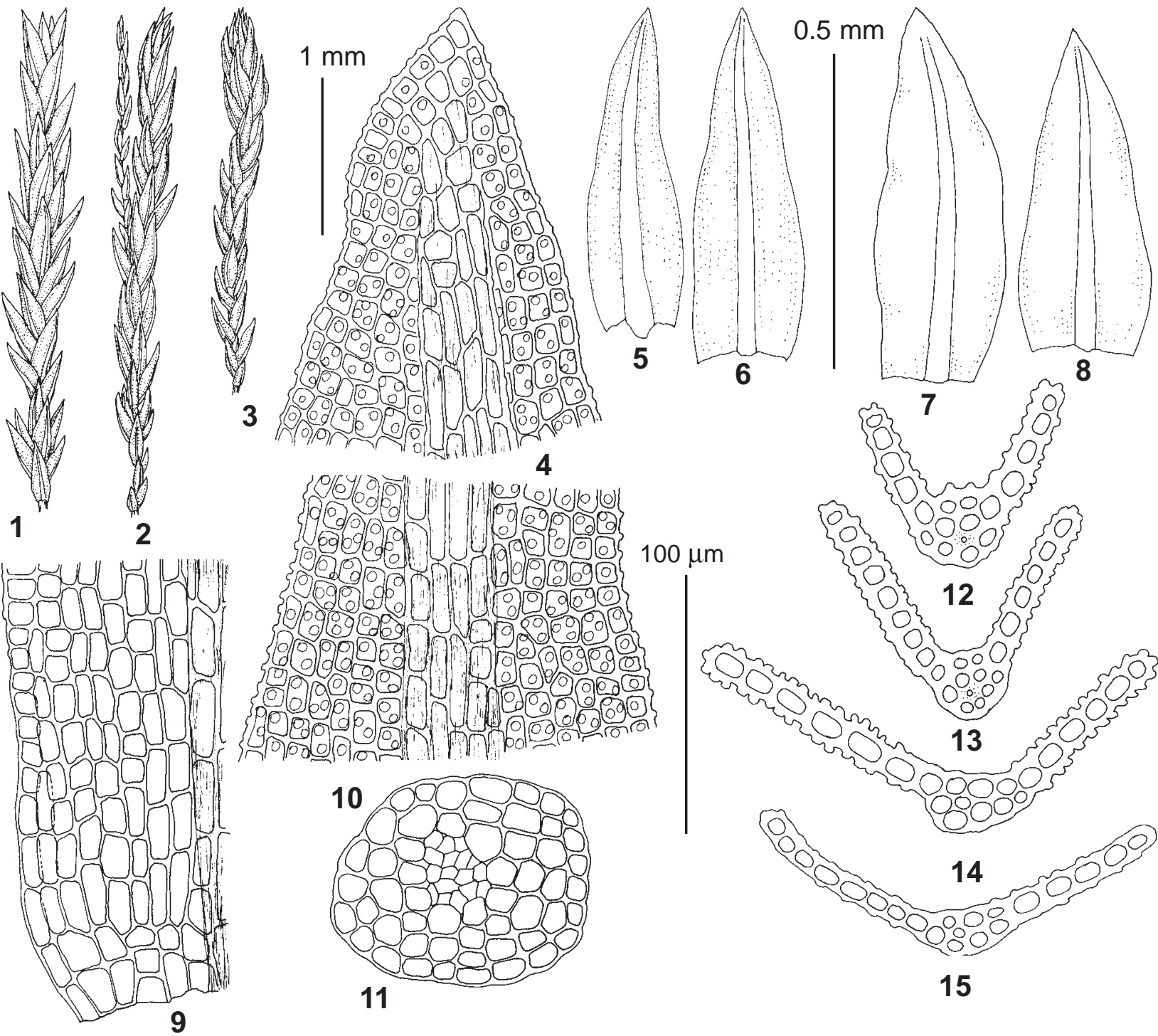

11

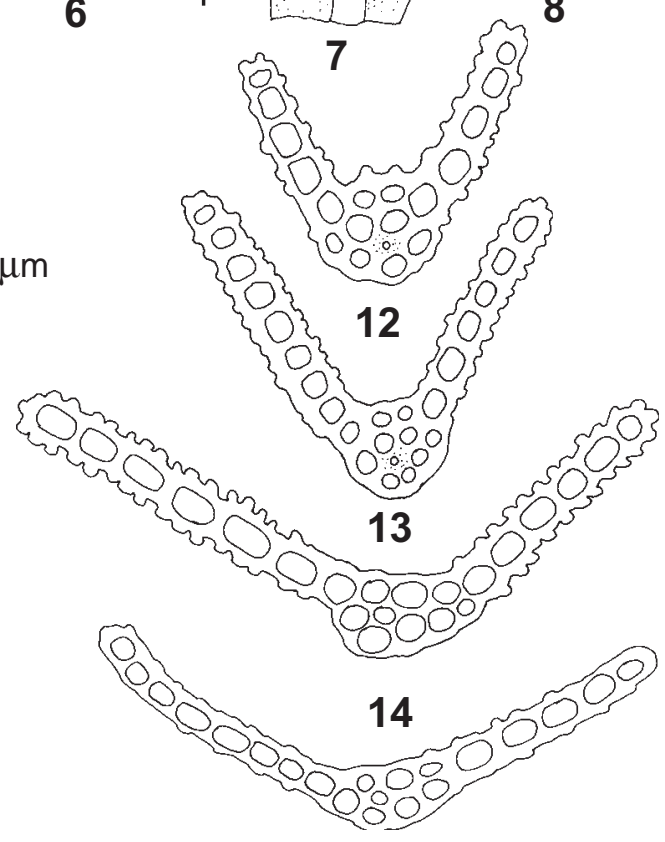

15

Fig. 4. Hymenostylium gracillimum (Irkutsk Province, Sakhyurta, 31.VIII.1997, Bardunov s.n., IRK, MW): 1 - habit, wet; 2-3 habit, dry; 4 - upper laminal cells; 5-8 - leaves; 9 - basal laminal cells; 10 - mid-leaf cells; 11 - stem transverse section; 12-15 - leaf transverse sections. Scale bars: $1 \mathrm{~mm}$ for $1-3 ; 0.5 \mathrm{~mm}$ for $5-8 ; 100 \mu \mathrm{m}$ for $4,9-15$.

burgh, and further processed with other samples specified in the Appendix in the molecular laboratory of the Department of Botany at University of South Bohemia following the protocols described in Kučera \& al. (2019). The laboratory protocols for specimens Ignatov \& Ignatova 15-851 and Bardunov s.n. were processed at the Tsitsin Main Botanical Garden following the protocols described in Fedosov et al. (2016).

The choice of analysed taxa was guided by the previously published account by Köckinger \& Kučera (2011), and restricted to the tribe Pleuroweisieae. The earlier selection of taxa was supplemented by accessions of Anoectangium thomsonii Mitt., Tuerckheimia valeriana (E.B.Bartram) R.H.Zander, Hymenostylium xanthocarpum (Hook.) Brid. and H. aurantiacum Mitt., and the species already used in that study were complemented with additional material in cases when the original selection included only one accession per species.
Sequences were aligned using MAFFT v. 7.402 (Katoh \& Standley, 2013) using the E-INS-i strategy and fine-tuned manually. ITS and concatenated chloroplast matrix included accessions from the same isolates but were analysed separately. For chloroplast matrix, indels were scored using the simple indel coding method (Simmons \& Ochoterena, 2000), whereas indel data were not used for ITS matrix due to the complexity of the alignment. The analyses included Bayesian Inference (BI) and Maximum Likelihood (ML), using the MrBayes 3.2.6 (Ronquist et al., 2012) and RAxML v. 8.2.8 (Stamatakis, 2014) software packages run at the cluster computer facilities of MetaCentrum VO (see Acknowledgement). For the parameters of the analyses, see Kučera \& al. (2019). TreeGraph 2 (Stöver \& Müller, 2010) was finally used to summarise the topology and support from different analyses, and the resulting trees were then further edited graphically in the Inkscape v.0.92 program under the GPLv2+ licence. Trees were rooted with Leptobarbula berica. 


\section{RESULTS}

Barcoding. Only ITS2 was obtained from the Omani specimen Frey \& Kürschner 1-3949, the two Russian samples yielded the complete ITS region and chloroplast data were obtained from all three samples and loci. The Omani sample of the morphologically putative $H$. xerophilum was fully identical in ITS2 (ITS1 could not be obtained) and trnM-trnV with the European samples of that species and differed in one substitution in rps4. The Russian sample of the morphologically putative $H$. xerophilum was identical in trnM-trnV with the European samples, differed in two substitutions in rps 4 (one shared with the Omani sample), and also differed in one ITS1 and one ITS2 substitutions from the European samples. The unnamed Baikal Hymenostylium shared fully the rps 4 sequences of European samples of $H$. gracillimum and differed in one substitution from the Austrian samples of trnM-trnV from that species (the Karelian sample of $H$. gracillimum from the paratype of Gymnostomum boreale differed in 3 substitutions and $3 \mathrm{~T}$-deletions in one poly- $\mathrm{T}$ region of the trnM-trnV spacer from the remaining samples of that species). The ITS region of the Baikal sample agreed with the Austrian samples of $H$. gracillimum except for one singlebase insert in ITS1 and one substitution in ITS2, shared with the Karelian sample (which differed in 3 additional substitutions in ITS2 from the other $H$. gracillimum samples). Within the whole trees, both putative plants of $H$. xerophilum were included in the lineages formed by the other accessions of that species (PP1 in chloroplast dataset and $\mathrm{PP}=0.74$ in the ITS dataset), the Baikal Hymenostyli$u m$ was nested in the $H$. gracillimum lineage with full support in the chloroplast dataset and it formed one leaf tip in the paraphyletic grade representing that species in the ITS phylogeny (Figs. 1, 2).

Morphology. Morphology of the Russian plants of H. xerophilum (Fig. 3) agrees well with the description provided by Köckinger \& Kučera (2011), although in small plants the leaves are only indistinctly twisted when dry. The Omani sample is unusually stunted, with leaves ovate, only $0.35-0.55 \mathrm{~mm}$ long and rounded at apex, although the costa remains typically wide, $45-50 \mu \mathrm{m}$, hardly narrowed towards the apex. The general shape markedly approaches the morphology of Gymnostomum mosis (which was the original identification, confirmed even by Whitehouse \& Crundwell in their treatment (1991)); it differs, however, in the elongate adaxial superficial costa cells, less papillose lamina cells and completely unistratose leaf lamina. Morphology of the sample of Hymenostylium from Irkutsk Province (Fig. 4) differs from the description of $H$. gracillimum as indicated by Köckinger \& Kučera (2011) in the leaves being rather short and slightly wider, $0.5-0.6 \mathrm{~mm}$ long and $0.15-0.20$ $\mathrm{mm}$ wide, with length:width ratio $2.75-3.5$ : 1 (vs. usually $4-12: 1$, rarely $3: 1$ ); the costa smooth on ventral surface or rarely with few papillae in distal portion (vs. usually papillose), poorly differentiated in cross section, with- out or with single dorsal stereid cells. The plant is rather similar to $H$. xerophilum in general appearance in the small size of plants, not or weakly branched stems, whitish subterranean rhizoids, stem transverse section with clearly differentiated central strand and almost undifferentiated sclerodermis, lanceolate keeled leaves with rather broadly acute apices, subpercurrent costa and distal laminal cells covered with rounded papillae. The plants from Irkutsk Province differ from both $H$. xerophilum and the common phenotype of $H$. gracillimum in the leaf lamina flat to slightly convex vs. often concave from abaxial view, costa slightly narrowed from leaf base to apex vs. costa hardly becoming narrower towards the apex, and in the transverse section of the costa weakly differentiated, without or with single stereids vs. well differentiated, with two stereid bands and dorsal and ventral epidermis, and in the costa surface cells smooth on both sides vs. papillose on adaxial side and smooth to variously papillose on abaxial side.

Ecology. The Yakutian locality of Hymenostylium xerophilum (Fig. 5) is a bald hill composed of peculiar rock, which probably contains a toxic concentration of heavy metals. The neighbouring slopes are covered with light Larix forests, at places open, with large stands of Cladonia stellaris (Opiz) Pouzar \& Vězda and screes in the steepest places. The foothill at $625 \mathrm{~m}$ harboured, among others, Aloina rigida (Hedw.) Limpr., Anomobryum bavaricum (Warnst.) Holyoak \& Köckinger, $A$. concinnatum (Spruce) Lindb., and Pterygoneurum ovatum (Hedw.) Dixon, which is rare in the boreal zone. In the vicinity of $H$. xerophilum population at $765 \mathrm{~m}$ we recorded Encalypta mutica I. Hagen, Timmia sibirica Lindb. \& Arnell, Molendoa sendtneriana (Bruch \& Schimp.) Limpr., Flexitrichum gracile (Mitt.) Ignatov \& Fedosov, Buckia vaucheri (Lesq.) D. Ríos, M.T. Gallego \& J. Guerra, Cyrtomnium hymenophylloides (Huebener) T.J. Kop., Dicranum elongatum Schleich. ex Schwägr., D. bardunovii Tubanova \& Ignatova, and two especially interesting species, Tortella densa (Lorentz \& Molendo) Crundw. \& Nyholm and Indusiella thianschanica Broth. \& Müll. Hal. We have no other information than the label data for the Omani specimen of H. xerophilum, which reads "rock fissures, calcareous, at 2050 m". Al Jabal Al Akhdar or Jebel Akhdar ("Green Mountains" is a mainly limestone mountain range ca 100 $150 \mathrm{~km}$ inland from the coast of the Gulf of Oman, which receives about $300 \mathrm{~mm}$ of precipitation at higher altitudes, which support some shrubby and tree vegetation and agriculture. The locality of $H$. gracillimum in Irkutsk Province is situated at the NW shore of Baikal Lake, at ca. $460 \mathrm{~m}$ a.s.1., in a place which is known as extremely dry and sunny; annual precipitation does not exceed 140 $\mathrm{mm}$ and mean annual number of cloudy days is only 48 (Voloshin et al., 2009). According to label data, the specimen of $H$. gracillimum was collected in fissures of a limestone cliff. 

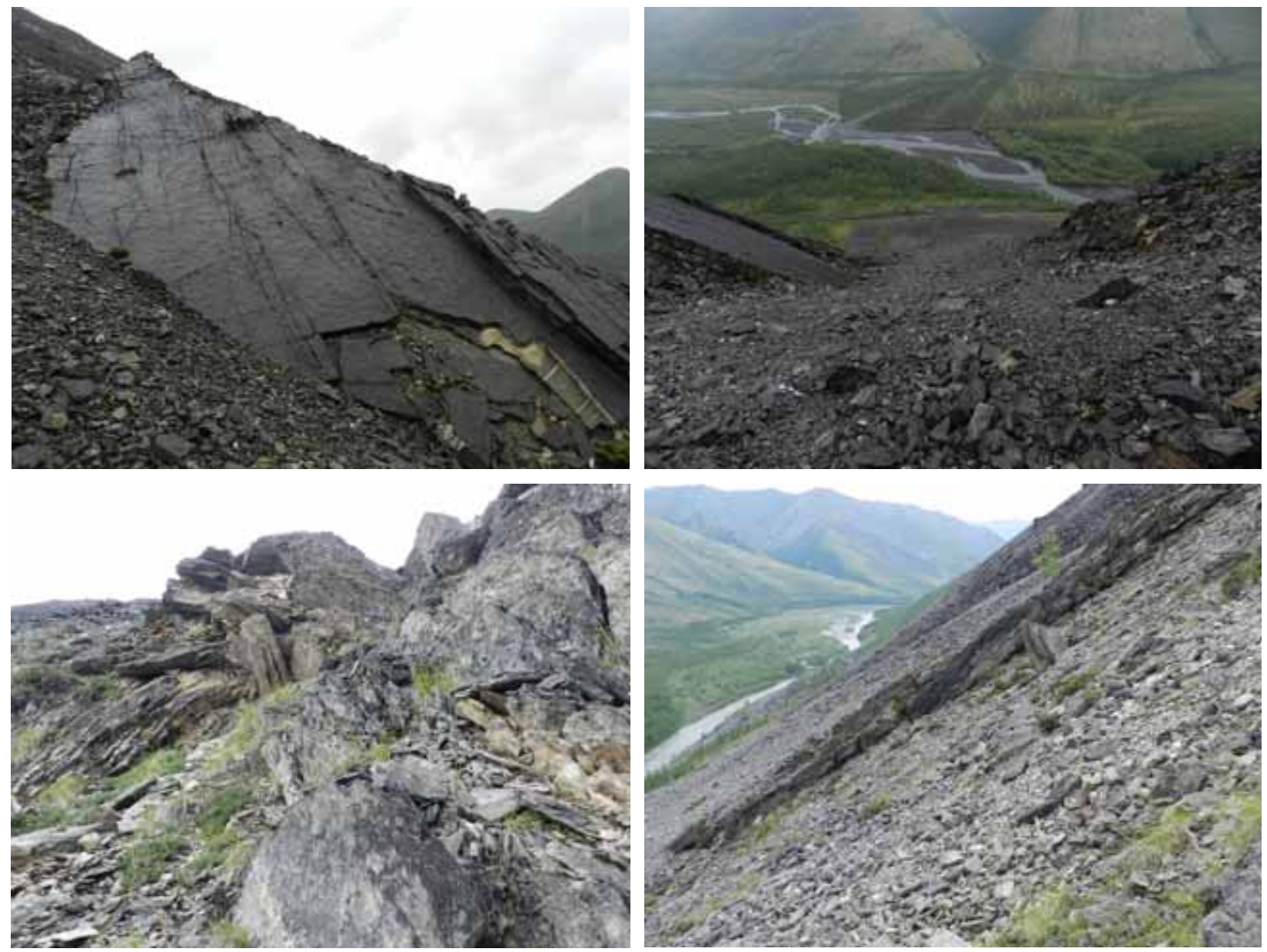

Fig. 5. Habitat of Hymenostylium xerophilum in Yakutia.

Phylogeny of Pleuroweisieae. The trees resulting from the analysis of nuclear (Fig. 1) and chloroplast loci (Fig. 2) agree in the basal position of Gyroweisia tenuis (Hedw.) Schimp. lineage with respect to the well supported crown group of Pleuroweisieae taxa, represented by accessions of Anoectangium, Tuerckheimia, Molendoa and Hymenostylium. They also agree in the supported monophyly of analysed taxa of Gymnostomum, Anoectangium and Molendoa, and non-monophyly of Tuerckheimia and Hymenostylium, as well as the monophyly of Hymenostylium xerophilum + gracillimum lineage, being a sister to the rest of Hymenostylium taxa, which constitute another moderately- to well-supported lineage. Analyses based on the nuclear and chloroplast loci differ, however, in the mutual position of Gymnostomum, Anoectangium and Tuerckheimia lineages, as well as among the taxa of the main Hymenostylium lineage, which includes the type of the genus, $H$. xanthocarpum. Therefore, we have not concatenated the data from the different genomic compartments and present the results from the analyses of nuclear and chloroplast datasets separately.

The additional accessions of Hymenostylium recurvirostrum s.lat. suggest a large genetic differentiation of this group and the potential for delimitation of addition- al taxa, particularly if var. insigne should continue to be recognised. The two analysed accessions of that taxon form a well-supported lineage according to the chloroplast data but not according to ITS, which is however nested among accessions with the general morphology of var. recurvirostrum. Hymenostylium xanthocarpum which has been recognised as the sole member of this genus upon the recognition of genus Ardeuma R.H. Zander \& Hedd. by Zander (2016) was found nested in the lineage containing H. (Ardeuma) aurantiacum and H. (Ardeuma) hildebrandtii (Müll. Hal.) R.H. Zander (chloroplast data).

Within the clade of $H$. xerophilum $+H$. gracillimum, the current analyses confirmed the uncertain position of the Karelian specimen of $H$. gracillimum (paratype of $G$. boreale), which clusters with a weak support (BS 60/PP 0.98 ) with the lineage of $H$. xerophilum in the ITS analysis. The results of concatenated analysis (not shown), however, agree with the results of chloroplast analysis.

\section{DISCUSSION}

Köckinger \& Kučera (2011) anticipated that the real distribution of both the newly described Hymenostylium xerophilum and the resurrected $H$. gracillimum will be broader than the European occurrences known at the time 
of publication. Particularly the mountain ranges of southern Siberia are the area with many elements common to European mountain ranges, including those known from the Alps, Carpathians and Dinaric mountain ranges. Olkhon Island is a very dry area despite it is an island in Lake Baikal. Western coastal ranges of Baikal provide the "wind shade" making Olkhon an almost cloudless area with only $140 \mathrm{~mm}$ of annual precipitation, vegetated by steppes which include endemics, such as Deschampsia turczaninowii Litv., Festuca baicalensis (Griseb.) V. Krecz., F. olchonensis E. Alexeev, Papaver olchonensis Peschkova, Dracocephalum olchonensis Peschkova, etc. (Zarubin \& Lyakhova, 1999). The widespread Mongolian and Central Asian grass Achnatherum sibiricum (L.) Keng ex Tzvelev survives here at the northern limit of its range in this longitudinal sector (https://www.gbif.org/ species/4141276 accessed 1 Dec 2019). However, the surroundings of Olkhon Island are fairy diverse, with outcrops of both marble and acidic rocks. According to the label data, $H$. gracillimum was collected on limestone cliffs, but details of site conditions are unknown. In Europe, the species prefers moist and shady, easily disintegrating rocks (typically phyllite or other schists). Occurrences on hard rocks were known to be restricted to shaded $\mathrm{N}$-facing crevices, which was probably also the case of the Karelian locality, and rarely the species was collected on artificial walls in Central Europe (Köckinger \& Kučera, 2011)

The Yakutian locality of H. xerophilum was ecologically more like European occurrences. Although the species has not been recorded from metalliferous carbonatecontaining rocks in the Alps, dolomite itself can be regarded toxic for many species occurring on limestone without higher magnesium contents. The toxic concentration of heavy metals apparent from the lack of vegetation on mountain slopes at the Yakutian locality and the co-occurrence of metallophytic Coscinodon hartzii C.E.O. Jensen and Mielichhoferia spp., which were seen at several sites nearby, might be the reason for its rarity at the site, as the species has not been re-found despite a targeted search afterwards. On the other hand, this environment can be considered stable, allowing the colonisation by tolerant species of different geographical elements, including pan-xeric (Frey \& Kürschner, 1988) Pterygoneurum and Aloina species, cryoarid Indusiella thianschanica, Leptopterigynandrum spp., Coscinodon hartzii, or the more western Tortella densa and Anomobryum bavaricum. Indusiella was thought for a long time to be extremely rare in Russia, but recent exploration focused on its findings revealed ca. 10 localities in Yakutia (Ivanova et al., 2016, 2017, 2018; Ignatova et al., 2018). The locality of Tortella densa is one of only two localities known so far in Yakutia, the second being ca. $50 \mathrm{~km}$ apart. The bedrock in this mountain range is fairly complex, including large limestone outcrops about $5 \mathrm{~km}$ from this locality, with the occurrence of Andreaeobryum macrosporum Steere \& B.M. Murray (Ignatov et al., 2018).
The mixture of geographic elements among mesophytic and hygromesophytic species of the Sette-Daban is also conspicuous: Beringian Andreaeobryum macrosporum, Haplodontium macrocarpum (Hook.) J.R. Spence, Schistidium relictum T.T. McIntosh, H.H. Blom \& Ignatova or Scouleria spp. co-occur here with the Central Asian Struckia enervis (Broth.) Ignatov, T.J. Kop. \& D.G. Long or the predominantly Sino-Himalayan Didymodon leskeoides K. Saito, Hydrogonium gregarium (Mitt.) Jan Kučera and $H$. amplexifolium (Mitt.) P.C. Chen.

While even the new, highly disjunct Asian records of H. xerophilum do not significantly add to known molecular diversity of the species, the Omani population extends the known morphological plasticity considerably, showing that round-leaved forms similar to Gymnostomum mosis and G. viridulum must be expected under particularly arid and warm site conditions. Similarly, the Siberian population of $\mathrm{H}$. gracillimum represents a significant addition to the known morphological variability of this species, making the distally vanishing costa in the latter species one of the few rather safe diagnostic characters between the species. The molecular divergence of the new Asian record, on the other hand, does not seem to be too high, being considerably smaller than that of the Karelian plants.

The phylogenetic affinities of Hymenostylium xerophilum and $H$. gracillimum with other Hymenostylium taxa have not changed significantly as compared to Köckinger \& Kučera (2011), despite the addition of several taxa of the genus, the generally better representation of Pleuroweisieae and the addition of one chloroplast locus. This study does not confirm Zander's arguments for segregating H. xanthocarpum into a monotypic Hymenostylium while moving all other species to a newly established genus, Ardeuma (Zander 2016). H. xanthocarpum is clearly nested (on a relatively short branch, showing a little genetic divergence from the other species) inside a lineage that contains most other Hymenostylium species, including the generitype of Ardeuma, H. recurvirostrum. Ardeu$m a$ was proposed as a new genus mainly based on the absence of the stem central strand, which might not be enough phylogenetically informative in this group of Pottiaceae. Interestingly, Zander has not proposed the generic affinity of $H$. xerophilum and $H$. gracillimum, which also possess the stem central strand, although he discussed the species. Despite Ardeuma can safely be merged with Hymenostylium based on the available molecular data, it is less clear whether the lineage containing $H$. xerophilum and $H$. gracillimum should be maintained within Hymenostylium or segregated to another morphologically weakly delimited genus of Pleuroweisieae. The conservative solution which we retain here might however result in the later necessity of merging the whole genus Molendoa, which is principally recognised by the lateral position of perichaetia, with Hymenostylium. The final decision needs in our opinion a much wider representation of Hymenostylium and Hymenostylium-related taxa. 


\section{ACKNOWLEDGEMENTS}

Financial support for molecular analyses from the institutional resources at the Faculty of Science, University of South Bohemia, is greatly acknowledged by JK, as well as the laboratory work of Alžběta Manukjanová in the Plant Molecular Laboratory at the workplace of JK. Jan Kučera acknowledges the financial support by the SYNTHESYS programme (GB-TAF-3543), which enabled the study of RBG Edinburgh collections (E). Computational resources ('Metacentrum VO') were supplied by the Ministry of Education, Youth and Sports of the Czech Republic under the Projects CESNET (Project No. LM2015042) and CERIT-Scientific Cloud (Project No. LM2015085) provided within the program Projects of Large Research, Development and Innovations Infrastructures.

The work of MI was conducted under institutional project AAAA-A16-116021660039-1, AF under 118021490111-5.

\section{LITERATURE CITED}

FEDOSOV, V.E., A.V. FEDOROVA, A.E. FEDOSOV \& M.S. IGNATOV. 2016. Phylogenetic inference and peristome evolution in haplolepideous mosses, focusing on Pseudoditrichaceae and Ditrichaceae s. 1. - Botanical Journal of the Linnean Society 181(2): 139-155. https://doi.org/ 10.1093/sysbio/49.2.369

FEDOSOV, V.E., E.A. IGNATOVA, M.S. IGNATOV \& A.I. MAKSIMOV. 2011. Rare species and preliminary list of mosses of the Anabar Plateau (Subarctic Siberia). - Arctoa 20: 153-174.

FREY, W. \& H. KÜRSCHNER. 1988. Bryophytes of the Arabian Peninsula and Socotra. Floristics, phytogeography and definition of the xerothermic Pangean element. Studies in Arabian bryophytes 12. - Nova Hedwigia 46: 37-120.

IGNATOV, M.S., O.M. AFONINA, E.A. IGNATOVA et al. 2006. Checklist of mosses of East Europe and North Asia. - Arctoa 15: 1-130.

IGNATOV, M.S., E.A. IGNATOVA, E.I. IVANOVA, O.V. IVANOV \& N.A. BYSYIN. 2018. On the distribution of Andreaeobryum in Russia. - Arctoa 27(2): 112-118

IGNATOVA, E.A., E.I. IVANOVA \& M.S. IGNATOV. 2018. Moss flora of Sette-Daban Range (Yakutia). - Arctoa 27(2): 119-130.

IVANOVA, E.I., E.A. IGNATOVA, V.G. ISAKOVA, I.A. BALAKIREV, O.I. KUZNETSOVA \& M.S. IGNATOV. 2018. Moss flora of the UstNera region in the upper course of Indigirka River, East Yakutia. Arctoa 27(1): 18-28. DOI 10.15298/arctoa.27.02
IVANOVA, E.I., V.G. ISAKOVA, M.S. IGNATOV \& E.A. IGNATOVA. 2017. On the moss flora of Khangalassky District (Republic of Sakha/ Yakutia, East Siberia). - Arctoa 26(1): 47-57. DOI: 10.15298/arctoa. 26.04

IVANOVA, E.I., E.A. IGNATOVA \& M.S. IGNATOV. 2016. Moss flora of the Suntar-Khayata Reserve, Yakutia). - Arctoa 25: 131-140. DOI: 10.15298/arctoa

KATOH, K. \& D.M STANDLEY. 2013. MAFFT Multiple Sequence Alignment Software Version 7: Improvements in Performance and Usability. - Molecular Biology and Evolution 30: 772-780. DOI: 10.1093/molbev/mst010

KÖCKINGER, H. \& J. KUČERA. 2011. Hymenostylium xerophilum, sp. nov., and $H$. gracillimum, comb. nov., two neglected European mosses and their molecular affinities. - Journal of Bryology 33(3): 195-209.

KUČERA, J., O.I. KUZNETSOVA, A. MANUKJANOVÁ \& M.S. IGNATOV. 2019. A phylogenetic revision of the genus Hypnum: Towards completion. - Taxon DOI: 10.1002/tax.12095

RONQUIST, F., M. TESLENKO, P. MARK. VAN DER, D.L. AYRES, A. DARLING, S. HÖHNA, B. LARGET, L. LIU, M.A. SUCHARD \& J.P. HUELSENBECK. 2012. MrBayes 3.2: Efficient Bayesian phylogenetic inference and model choice across a large model space. - Systems Biology 61: 539-542. DOI: 10.1093/sysbio/sys029

SIMMONS, M.P. \& H. OCHOTERENA. 2000. Gaps as Characters in Sequence-based Phylogenetic Analyses. - Systematic Biology 49: 349-381.

STAMATAKIS, A. 2014. RAxML version 8: a tool for phylogenetic analysis and post-analysis of large phylogenies. - Bioinformatics 30(9): 1312-1313, DOI: 10.1093/bioinformatics/btu033

STÖVER, B.C. \& K.F. MÜLLER. 2010. TreeGraph 2: Combining and visualizing evidence from different phylogenetic analyses. - B. M. C. Bioinformatics 11: 7. DOI: 10.1186/1471-2105-11-7

[VOLOSHIN, A.L., S.G. ANDREEV \& V.N. PRONIN] ВОЛОШИН А.Л., С.Г. АНДРЕЕВ, В.Н. ПРОНИН. 2009. Климатические особенности. - [Climate patterns] В кн.: Тулохонов. А.К. (ред.) Байкал. Природа и люди [In: Tulokhonov, A.K. (ed.) Baikal. Nature and people] Улан-Удэ: ЭКОС, Изд-во БНЦ СО РАН [Ulan-Ude, EKOS publishing house of BSC SB of RAS], 606 pp.

WHITEHOUSE, H.L.K. \& A.C. CRUNDWELL. 1991. Gymnostomum calcareum Nees \& Hornsch. and allied plants in Europe, North Africa and the Middle East. - Journal of Bryology 16: 561-579.

ZANDER, R.H. 2016. Re-evaluation of Hymenostylium xanthocarpum (Hook.) Brid., and Ardeuma R.H.Zander \& Hedd., a new name for all other species of Hymenostylium (Pottiaceae, Bryophyta). - Journal of Bryology 38: 295-301.

Appendix 1. Specimen used in the molecular analyses, with GenBank accession numbers. Accessions printed in bold were newly obtained for this study.

Species

Anoectangium aestivum Anoectangium aestivum Anoectangium aestivum

Anoectangium thomsonii

Anoectangium thomsonii Anoectangium thomsonii Gymnostomum calcareum Gymnostomum calcareum Gymnostomum calcareum Gymnostomum calcareum
Specimen voucher

Isolate

Genbank code (ITS/rps4/trnM-trnV)

Austria, Heiligenblut, Kučera 12848 (CBFS) JK104 UK, Ben Earb, Kučera 10128 (CBFS) JK658 Norway, Divielva valley, Kučera 15892 AM682 HM147801/ HM147774/ JX679910 (CBFS)

Japan, Honshu, Okawara, Y. Inoue 1281 AM678 (CBFS)

Russia, Zabaykalsky, Afonina 6612 (CBFS) AM698

China, Yunnan, Bai Ma Shan, Long 24221 (E) RBGE885 Switzerland, Muzzano, Kučera 6508 (CBFS) JK177 Greece, Ourlias River, Blockeel 39/274

Greece, Samos, Blockeel 41/056

AM704

Chile, XII, Cueva del Milodón, Sérgio 12804 AM718 (LISU)
MN817235/ MN815933/ MN815965

MN817236/ MN815934/ MN815966

MN817237/ MN815935/ MN815967

MN817238/ MN815936/ MN815968 MN817239/ MN815937/ MN815969 HM147812/ HM147786/ MN815970 MN817240/ MN815938/ MN815971 MN817242/ MN815940/ MN815973 
Gymnostomum viridulum Gymnostomum viridulum Gyroweisia tenuis Gyroweisia tenuis Hymenostylium aurantiacum Hymenostylium aurantiacum Hymenostylium gracillimum

Hymenostylium gracillimum

Hymenostylium gracillimum Hymenostylium gracillimum

Hymenostylium gracillimum

Hymenostylium hildebrandtii Hymenostylium recurvirostrum var. recurvirostrum

Hymenostylium recurvirostrum Tajikistan, Iskanderkul, Plášek s.n. (CBFS) JK646 var. recurvirostrum

Hymenostylium recurvirostrum Austria, Bürser Schlucht, H. Köckinger var. recurvirostrum 14935 (CBFS)

Hymenostylium recurvirostrum Austria, Haselschlucht ravine,

var. insigne Schlüsslmavr s.n. (CBFS)

Hymenostylium recurvirostrum UK, VC108, Inchnadamph, Long 29181 var. insigne (E)

Hymenostylium recurvirostrum India, Mussoorie, Lüth 6625

s.lat.

Hymenostylium recurvirostrum Japan, Honshu, Kamimura, Y. Inoue 1323

s.lat. (CBFS)

Hymenostylium recurvirostrum Greece, Mt Timfi, Blockeel 37/253

s.lat.

Hymenostylium recurvirostrum Russia, Zabaykalsky, Koira creek,

s.lat. Afonina 6612 (CBFS)

Hymenostylium recurvirostrum Russia, Irkutskaya, Slyudyanka, Kučera

s.lat. 20804 (CBFS)

Hymenostylium xanthocarpum India, Mussoorie, Lüth 6624

Hymenostylium xanthocarpum India, Mussoorie, Lüth 6596

Hymenostylium xerophilum

Hymenostylium xerophilum 05-954 (CBFS)

Austria, Carinthia, Krastal valley, JK100 Köckinger 14243 (CBFS)

Hymenostylium xerophilum Oman, Jabal Al Akhdar, Frey \& Kürschner AM902 1-3949 (E)

Hymenostylium xerophilum

Leptobarbula berica Leptobarbula berica Molendoa hornschuchiana

Molendoa hornschuchiana Molendoa sendtneriana

Molendoa sendtneriana

Molendoa tenuinervis

Molendoa tenuinervis

Tuerckheimia svihlae

Tuerckheimia svihlae Tuerckheimia valeriana
Russia, Sakha, Ignatov \& Ignatova 15-851 AF1142 (MHA)

Spain, Murcia, Kučera 13640 (CBFS) JK380

Spain, Andalucía, Kučera 17430 (CBFS)

Austria, Seidlwinkltal valley, Kučera 12790 (CBFS)

Austria, Heiligenblut, Kučera 6341 (CBFS)

Russia, Sakha, Lenskiye Stolby, Ignatov 00-258 (CBFS)

Austria, Heiligenblut, Kučera 12838 (CBFS)

Mongolia, Mt. Ikh-Bogd, Ignatov 01-789 (CBFS)

Austria, Mt Hohe Dock, Kučera 12768 (CBFS)

U.S.A., Florida, Marianna Caverns, Cash \& Rapp $M 193$ (DUKE)

China, Yunnan, Shabadi, Long 32566 (E) Costa Rica, Río Savegre, Holz \& Schäfer-Verwimp CR 99-1178 (E)

JK108
HM147797/ HM147770/ JQ890412 MN817243/ MN815941/ MN815974 HM147799/ HM147772/ JX679908 MN817244/ MN815942/ MN815975 MN817245/ MN815943/ MN815976 MN817246/ MN815944/ MN815977 HM147809/ HM147782/ JQ890413

HM147811/ HM147784/ MN815978 HM147815/ HM147789/ MN815979 HM147818/ HM147792/ MN815980

MN817247/ MN815945/ MN815981

AY796282/ HM147793/ MN815982 HM147800/ HM147773/ JX679909

MN817249/ MN815947/ MN815984

MN817253/ MN815951/ MN815988

HM147810/ HM147783/ MN815990

MN817255/ MN815953/ MN815991

MN817248/ MN815946/ MN815983

MN817250/ MN815948/ MN815985

MN817251/ MN815949/ MN815986

MN817252/ MN815950/ MN815987

MN817254/ MN815952/ MN815989

MN817256/ MN815954/ MN815992

MN817257/ MN815955/ MN815993

HM147796/ HM147769/ JQ890415

HM147798/ HM147771/ MN815994

MN817258/ MN815956/ MN815995

MN817259/ MN815957/ MN815996

MN817260/ MN815958/ MN815997 AM1050 MN817261/ MN815959/ MN815998 JK106 HM147802/ HM147775/ MN815999

JK663 MN817262/ MN815960/ MN816000 JK181 HM147813/ HM147787/ MN816002

JK107 MN817263/ MN815961/ MN816001

JK134 JQ890531/ JQ890478/ JQ890417

MN817264/ MN815962/ MN816003

JK312 HM147817/ HM147791/ JX679914

RBGE822 MN817265/ MN815963/ MN816004 RBGE821 AY854431/ MN815964/ MN816005 